\title{
FACTORS ASSOCIATED WITH THE ADOPTION OF FOOD SAFETY CONTROLS BY THE MEXICAN MEAT INDUSTRY
}

\author{
Ema Maldonado-Simán ${ }^{1, *}$, Pedro Arturo Martínez-Hernández ${ }^{1}$, José G. \\ García-Muñiz ${ }^{1}$, José Cadena-Meneses ${ }^{1}$ \\ ${ }^{1}$ Posgrado en Producción Animal. Universidad Autónoma Chapingo. Km. 38.5 Carretera \\ México-Texcoco. 56230. Texcoco, Edo. de México. \\ * Corresponding author, Address: Posgrado en Producción Animal, Universidad Autónoma \\ Chapingo. Km. 38.5 Carretera México-Texcoco. 56230. Texcoco, Edo. de México, Tel: \\ +52-(595)95216-21, Fax:+52-(595)95216-89, Email: mamaldonado@correo.chapingo.mx
}

\begin{abstract}
Food marketing at international and domestic markets has focused on processing systems that improve food safety. The objective of this research is to determine the factors influencing the implementation of the HACCP system in the Mexican meat industry, and to identify the main marketing destination of their products. Only $18.5 \%$ of enterprises reports fully operational HACCP in their plants. The main destination of their production in the domestic market is supermarkets, suppliers and distributors and specific niches of the domestic market. Exports are to USA, Japan, Korea and Central America and some niches of the domestic market with requirements of higher quality. The four principal factors that motivate enterprises to adopt HACCP are associated with improvement of plant efficiency and profitability, adoption of good practices, improvement of product quality and waste reduction. It is concluded that Mexican enterprises adopt HACCP to successfully remain and face competition by foreign enterprises in the domestic market and to a lesser extent to compete in the international market.
\end{abstract}

Keywords: $\quad$ Factors, HACCP adoption, Mexican meat industry

Please use the following format when citing this chapter:

Maldonado-Simán, E., Martínez-Hernández, P.A., García-Muñiz, J.G., Cadena-Meneses, J., 2009, in IFIP International Federation for Information Processing, Volume 295, Computer and Computing Technologies in Agriculture II, Volume 3, eds. D. Li, Z. Chunjiang, (Boston: Springer), pp. 1739-1746. 


\section{INTRODUCTION}

Food safety is the common ground for developing and developed countries in the food commercial trade (Maldonado et al., 2005). International and domestic markets experienced important changes due to the jointly application of government and private regulatory requirements and standards along all the food chain, in order to satisfy the increased demands for food safety. (Caswell et al., 1998). Meat industry in Mexico includes Federal Inspection Type (TIF) enterprises that slaughter domestic animals, and others that carry out transformation processes as cuts, boners, sausages and stuffers, meat patties, meat dehydration, preparation of diverse meat foods and tamales (SAGARPA, 2001). There is growing interest in food safety by local consumers that are better informed about disease outbreaks (OECD, 1999), which in turn has promoted more demanding market (Martin et al., 1993).

Along with a stiffer domestic market there is the increased competition of meat plants from countries that have Commercial Agreements with Mexico. Foreign enterprises offer food products processed under tighter safety controls (Caswell and Henson, 1997; Caswell et al., 1998), as Hazard Analysis Critical Control Points (HACCP) and international certification by the International Organization for Standardization (ISO 9000) (Caswell et al., 1998; Herrera, 2004). Government standards related to the food sector may be classified into two groups: one group is the set of standards that define type and final quality of the food product (Caswell and Johnson, 1991; Henson and Caswell, 1999; Henson y Caswell, 1999) and the other is the nutrimental information that must be provided to consumers by the enterprises (Henson, 1997). In Mexico, the National Plant and Animal Health and Food Safety and Quality Services (SENASICA), is the federal agency in charge of regulations and surveillance of food quality and safety (Constitución Política de los Estados Unidos Mexicanos, 2005; Ley de la Administración Pública Federal, 2003). Following political and economical demands of certain countries, food processing industries are required to apply effective food safety controls such as the HACCP System (Caswell and Henson, 1997), in addition to voluntary systems such as ISO 9000 and ISO 14000 (ISO, 1996; Noelke and Caswell, 2000). Food processing enterprises must face different economic and social factors, which determine the pressure in adopting these controls. These factors may be similar for enterprises that operate within the same sector, while among others, they arise from particular demands derived from the need to comply with regulations, avoid lawsuits related with food quality and safety, reduce internal and external costs or achieve a clear differentiation of product brand (Hooker and Caswell, 1999). 
Therefore, the objective of this study is to define the nature of the motives that lead Mexican Federal Inspection Type (TIF) enterprises in the adoption of the HACCP system in their plaints and the main market destination of their products.

\section{MATERIALS AND METHODS}

Field information for this study came from questionnaires (Henson et al., 1999; Maldonado et al., 2005; Martin et al., 1993) sent to the 160 TIF enterprises registered in the Official Listing of TIF Enterprises of the Ministry of Agriculture, Livestock, Rural Development, Fisheries and Food (SAGARPA) (SAGARPA, 2001). Questionnaires were filled out by direct interview, this field phase was from 2000 to 2001; in 2003, and the enterprises identified with a fully operational HACCP system were revisited to validate the accuracy of the information given in the questionnaire.

The questionnaire included a list of factors that in previous studies (Carlsson and Carlsson, 1996; Tompkin, 1994) were proposed as determinants for the enterprises in the adoption of food safety protocols. In order to assure a positive evaluation of the main motives that lead meat processing plants to the implementation of HACCP system, the first step taken was the classification of enterprises by the level of adoption of this system. Then, further analyses were performed only within the group of enterprises that showed the HACCP fully implemented and functional in their plants; these enterprises were then classified by size following the Food Safety and Inspection Service (FSIS) criteria (FSIS, 1996). Enterprises were asked to grade the importance of each deciding factor based on the Likert scale, grades were from 1(very important factor) to 7(not-important factor). After that, with the purpose of better understanding the incentives that the enterprises had to adopt HACCP, a Principal Components Analysis (PCA) was used (Henson and Holt, 1999).

\section{RESULTS}

Ninety-two (57.5\% of all registered Mexican TIF enterprises) answered and filled out the questionnaire. Within these enterprises four groups were identified in relation to the extent of adoption or interest in adopting the HACCP system (Table 1). Only $18.5 \%$ of the enterprises had fully operational HACCP system in their plants. Of the Mexican TIF enterprises that had an operational HACCP system $76.5 \%$ were small and medium size, while less than a third $(23.5 \%)$ of this group was represented by large size 
enterprises (Table 2). In general, fully implementation and operation of HACCP was relatively recent, since at least $75 \%$ of the enterprises did not have more than two years with HACCP system operating in their plants and approximately; $10 \%$ of them that had an operational HACCP at the time of the interview had it for about four years (Figure 1). These last enterprises could be considered the pioneers in the sector.

Table 1. Grouping of Mexican TIF enterprises based on HACCP implementation status

\begin{tabular}{lcc}
\hline \multicolumn{1}{c}{ HACCP status } & Number of enterprises & Proportion $(\%)$ \\
\hline Fully operational & 17 & 18.5 \\
Being implemented & 27 & 29.3 \\
Planned but not implemented & 30 & 32.6 \\
No plans to implement & 18 & 19.6 \\
\hline
\end{tabular}

In relation to participation in foreign markets, $47 \%$ of the enterprises send approximately $17 \%$ of their production to export, and the domestic market took the $83 \%$ of the production. Distribution of production within the domestic market was: $63.3 \%$ went to national supermarket chains and nation-wide distributors; $16.9 \%$ went to the major caterers; $10.6 \%$ to meat plants for further processing; 5.3 and $3.9 \%$ to local wholesalers and final consumers, respectively. Therefore, the incorporation of the Mexican meat industry to international markets, in number and sale volumes, was incipient. Export destinations were USA, Japan, Korea, Central America and specific niches of the domestic market, such as transnational enterprises (restaurants and fast food chains).

Table 2. Size of Mexican TIF enterprises with fully operational HACCP

\begin{tabular}{lcc}
\hline Size (number of employees) & Number of enterprises & Proportion (\%) \\
\hline Small (10 to 200) & 7 & 41.2 \\
Medium (201 to 500) & 6 & 35.3 \\
Large (over 500) & 4 & 23.5 \\
Total & 17 & 100.0 \\
\hline
\end{tabular}

Factors that the enterprises considered of greater importance to make a decision in favor of implementing HACCP were related with legal requirements compliance as demanded by domestic and international markets, having access to international markets, and to be certified by a third party (Table 3 ). 


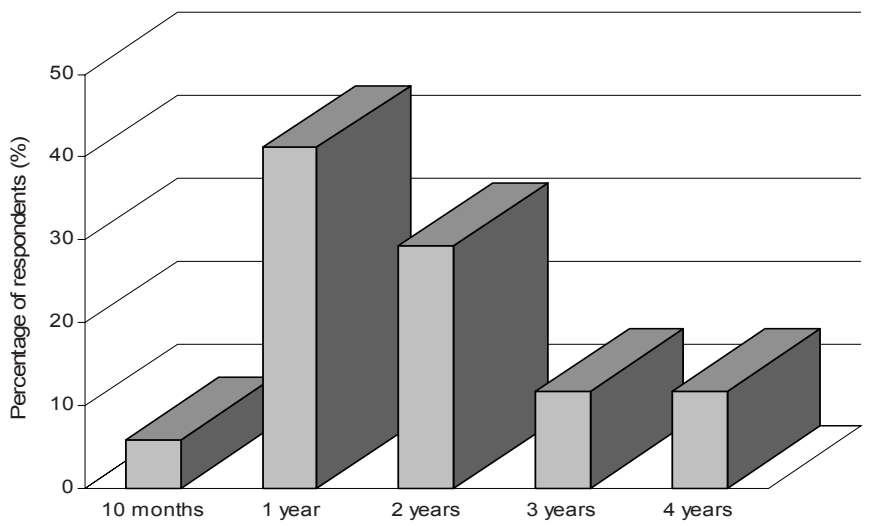

Fig. 1: Time intervals of Mexican TIF enterprises with fully operational HACCP

Seventy-one percent of the enterprises indicated that their current customers were asking them to have an operational HACCP system for all the products generated in their plants. This fact could indicate the importance that market regulations and incentives have on pressing Mexican meat enterprises to adopt food safety protocols.

Table 3. Mean importance scores in ascending order for factors influencing decision to develop/implement HACCP.

\begin{tabular}{lc}
\multicolumn{1}{c}{ FACTOR } & GRADE* \\
\hline Legal requirements & 1.24 \\
Have access to international markets & 1.41 \\
Need of plant certification by a third party & 1.71 \\
Improve product quality & 1.76 \\
Attract new customers for their products & 1.88 \\
Comply with demands of most of their customers & 1.94 \\
Improve production process control & 2.59 \\
Maintain existing clientele & 2.65 \\
Improve plant efficiency / profitability & 2.71 \\
Because it was considered a good practice & 3.53 \\
Reduce need for quality auditing by customers & 3.71 \\
Reduce product waste & 4.41 \\
Recommended by commerce organization & 5.06 \\
Reduce client complaints & 5.24 \\
\hline
\end{tabular}

* Grade scale was from 1 (very important deciding factor) to 7 (not-important factor in the decision making).

Four factors explained $69.8 \%$ of the variance in the selection of the 14 reasons based on the need to have the HACCP system implemented (Table 4). To enable the advantages derived by the implementation of the HACCP system in their plants, the largest variation proportion factor $(22.9 \%)$ included the following reasons: "plant efficiency and productivity 
improvement" and "maintaining existing clientele". Efficiency improvement is an internal factor, while clientele responds to a condition external to the plant." This suggests that this factor is associated firstly with the plant efficiency and then through clientele benefits as a major benefit associated to the HACCP system implementation and operation.

The second factor $(20.5 \%)$ included internal reasons, such as: "being a good practice" and "improving process control". This suggests that only internal factors are influential to this group of enterprises in order to implement HACCP in their plants. Third and fourth important factors with a total variance of 13.7 and $12.7 \%$, respectively, are also associated with internal reasons: "improving product quality" and "reducing product waste", respectively. Both suggest that these factors are associated with the product improvement as a major benefit derived from the HACCP system implementation and operation.

Table 4. Factor loadings for motivation to implement HACCP derived from principal components analysis.

\begin{tabular}{lcccc}
\hline \multicolumn{1}{c}{ Reason for implementation of HACCP } & Factor 1 & Factor 2 & Factor 3 & Factor 4 \\
\hline Comply with demands of their customers & 0.60610 & 0.04607 & -0.43834 & 0.55344 \\
Legal requirements & -0.07564 & -0.31224 & -0.02201 & -0.58168 \\
Improve production process control & 0.37980 & 0.67632 & -0.25184 & -0.15528 \\
Reduce product waste & -0.09597 & 0.43271 & 0.28037 & 0.66871 \\
Reduce client complaints & 0.44497 & 0.61000 & 0.38825 & -0.12471 \\
Improve plant efficiency / profitability & 0.87042 & 0.05919 & 0.21612 & 0.15484 \\
Improve product quality & 0.48784 & -0.04600 & 0.67501 & -0.17888 \\
Recommended by commerce organization & -0.31905 & -0.36915 & 0.49419 & 0.47458 \\
Reduce need for quality auditing by customers & 0.61004 & -0.51796 & -0.18694 & 0.39521 \\
Need of plant certification by a third party & -0.05413 & -0.59356 & -0.45168 & 0.29219 \\
Because it was considered a good practice & 0.03376 & 0.77908 & -0.29799 & 0.07104 \\
Maintain existing clientele & 0.77150 & -0.04119 & -0.30656 & -0.20216 \\
Attract new customers for their products & 0.54403 & -0.53632 & 0.43462 & -0.18414 \\
Have access to international markets & -0.35003 & 0.29732 & 0.17489 & 0.19548 \\
Proportion of variation explained & 22.9 & 20.5 & 13.7 & 12.7 \\
\hline
\end{tabular}

\section{DISCUSSION}

This analysis indicates that the adoption of the HACCP system is motivated by a wide range of factors, also reported in other studies (Caswell et al., 1998; Mortlock et al., 1999), which are related with internal and external factors to the enterprises. The most relevant internal factors for the TIF enterprises to make a decision to adopt the HACCP system are the fact of increasing plant efficiency and good practices during processing. To maintain existing clientele and comply with legal requirements are the most important external factors for this group of Mexican enterprises. 
Probably the size of the enterprise is another factor that influences the incentives for implementing HACCP, since the largest ones are the first in adopting and operating the HACCP system in Mexico. Evidences found in other studies (Holleran and Bredahl, 1997; Mortlock et al., 1999), suggest that the largest enterprises adopted this system before the smallest enterprises because of their own benefit expectations.

Mexican enterprises with HACCP system are placed as the most efficient ones in Mexico, with a strong presence in the domestic market and strength to cope with transnational enterprises that are trying to gain customers in this Mexican market on the bases of low number of complaints from unsatisfied customers. Evidence suggests that enterprises adopted food safety protocols as a mean to avoid lawsuits due to defective or unhealthy products placed in the market (Buzby et al., 2001; Henson and Holt, 1999) and with this they keep their local markets (Buchanan and Whiting, 1998).

It is concluded that the adoption of HACCP and ISO 9000 is associated with the goal of increasing sales due to a certified improvement in product quality, in addition to improvements in efficiency and yields of all internal processes. Mexican TIF enterprises adopted HACCP and ISO 9000 to comply with international market regulations and in order to maintain domestic customers with higher level demands on food quality and safety food products.

\section{ACKNOWLEDGMENTS}

We acknowledge the financial support of the Consejo Nacional de Ciencia y Tecnología (CONACYT); the assistance of Asociación Nacional de Empresas TIF (ANETIF) and their Managers and the Official TIF Veterinarians of Federal Inspection Type (TIF) enterprises.

\section{REFERENCES}

A.G. Herrera. The hazard analysis and critical control point system in food safety. Journal of Methods in Molecular Biology, 2004, 268:235-280.

C. M. Noelke, J. A. Caswell. A Model of the Implementation of Quality Management Systems for Credence Attributes. PhD dissertation. Department of Resource Economics. University of Amherst, Massachusetts. 2000.

Constitución Política de los Estados Unidos Mexicanos. Porrúa. México. 2005.

E. Holleran, M. E. Bredahl. Food Safety, Transaction Costs, and Institutional Innovation in the British Food Sector. Working Paper 97-1, Center for International Trade Studies, Missouri University. Columbia, MO. 1997. 
FSIS. Food Safety Inspection Service. Pathogen reduction: Hazard Analysis and Critical Control Point (HACCP) Systems; Final Rule. Federal Register. 61(144):38805-38889. United Sates Department of Agriculture, Washington. 1996.

ISO. ISO Standards Compendium-ISO 9000 Quality Management. International Organization for Standardization Geneva, Switzerland. 1996.

J. A. Caswell, G. V. Johnson. Firm Strategic Response to Food Safety and Nutrition Regulation. In: Economics of Food Safety, Julie A. Caswell, (ed.). pp. 273-297. New York: Elsevier Science, 1991.

J. A. Caswell, M. E. Bredahl, N. H. Hooker. 1998. How Quality Management Metasystems are affecting the Food Industry. Review of Agricultural Economics, 1998, 20: 547-557.

J. A. Caswell, S. J. Henson. Interaction of Private and Public Food Quality Control Systems in Global Markets. Paper presented at the conference Globalization of the Food Industry: Policy Implications. September. The University of Reading, United Kingdom, 1997.

J. C. Buzby, P. D. Frenzen, and B. Rasco. Product Liability and Microbial Foodborne Illness. Washington, DC. U.S. Department of Agriculture. Agr. Econ. Rep. No. 799. USDA/Economic Research Service, Food and Rural Economics Division, Washington, DC, 2001.

Ley de la Administración Pública Federal 2003. Porrúa. México.

M. Carlsson, D. Carlsson. Experiences of Implementing ISO 9000 in Swedish Industry. International Journal of Quality \& Reliability Management, 1996, 13:36-47.

M. P. Mortlock, A. C. Peters, C. J. Griffith. Food hygiene and hazard analysis critical control point in the United Kingdom food industry: practices, perceptions, and attitudes. Journal of Food Protection, 1999, 62:786-92.

N. H. Hooker, J. A. Caswell. 1999. Two Case Studies of Food Quality Management Systems. Journal of International Food \& Agribusiness Marketing, 11:57-71.

OECD. Food Safety and Quality: Trade Considerations. Organisation for Econ17461746omic Co-operation and Development. Paris. 1999.

R. B. Tompkin, HACCP in the Meat and Poultry Industry. Food Control, 1994, 5:153-161.

R. L. Buchanan, R. C. Whiting. Risk assessment: a means for linking HACCP plans and public health. Journal of Food Protection, 1998, 61:1531-1534.

S. A. Martin, B. J. Bowland, B. Calingaert, N. Dean. Economic Analysis of HACCP Procedures for the Seafood Industry. North Carolina: Research Triangle Institute. 1993.

S. E. Maldonado, S. J. Henson, J. A. Caswell, L. A. Leos, P. A. Martinez, G. Aranda, and J. A. Cadena. Cost-Benefit Analysis of HACCP Implementation in the Mexican Meat Industry. Food Control, 2005. 16:375-381.

S. J Henson, J. A. Caswell. Food Safety Regulation: An Overview of Contemporary Issues. Food Policy, 1999, 24:589-603.

S. J. Henson, G Holt, J. Northen. 1999. Cost and Benefits of Implementing HACCP in the UK Dairy Processing Sector. Food Control, 1999. 10:99-106.

S. J. Henson, G. Holt. Exploring Incentives for the Adoption of Food Safety Controls: HACCP Implementation in the U.K. Dairy Sector. Review of Agricultural Economics, 1999, 22(2):407-420.

S. J. Henson, J. A. Caswell. 1999. La regulación de la seguridad alimentaria: Perspectiva general de las cuestiones actuales. Revista Asturiana de Economía, 22:7-26.

S. J. Henson. Costs and Benefits of Food Safety Regulations. Paris: Organization for Economic Co-operation and Development. 1997.

SAGARPA. Directorio de Empresas Tipo Inspección Federal (TIF). Dirección de Rastros TIF. Dirección de Sanidad Animal. México. 2001. 